Arbejdspapirer fra Institut for Økonomi, Politik og Forvaltning

Business-Government Relations for Recently Privatized Companies

Carsten Greve

ISSN 1396-3503

$1997: 5$ 
Carsten Greve:

Business-Government Relations for Recently Privatized Companies

All Right Reserved

Department of Economics, Politics

and Public Administration

Aalborg University

Fibigerstraede 1

9220 Aalborg - Denmark

print: Kopicentralen

Aalborg 1997 


\title{
Business-Government Relations for Recently Privatized Companies
}

\author{
Carsten Greve \\ Department of Economics, Politics and Public Administration \\ Aalborg University \\ Fibigerstraede 1 \\ DK-9220 Aalborg \\ e-mail: greve@ socsci.auc.dk
}

Paper presented at The Eigth Annual Meeting of the International Association for Business and Society

Destin, Florida, USA

6-9 March 1997 


\title{
Business-Government Relations for Recently Privatized Companies
}

\author{
Carsten Greve \\ Aalborg University \\ Fibigerstraede 1 \\ DK-9220 Aalborg \\ Denmark \\ +4596358175 \\ +4598155346 fax \\ greve@socsci.auc.dk
}

How can the relationship between business and government be explained for recently privatized companies? The case of Denmark testifies that institutional theory emphasising "sticky" norm, values and rules cannot account for the companies' adaption to new conditions on competitive markets. Recently, privatized companies seem to lose their links to government in a short span of time.

\section{INTRODUCTION}

In recent years a number of public entreprises have been transformed into state owned enterprises in Denmark. By a state owned enterprise I mean one that is registrered as a private law company in which the government owns shares and have a decisive influence in strategic company matters. In some of these companies the government has sold assets to private investors, i..e. privatization in the strict sense of the term (Bös 1991; Vickers \& Yarrow 1991).

Historically, Denmark has not had many public enterprises, and privatization was not a widespread phenomenon, compared with bigger European countries like Britain, France or Italy (Parris, Pestiau \& Saynor 1987). Until 1990 the relationship between the Danish government and state owned companies had been one of tradition, trust and routine behaviour (Olsen 1993). The "players in the game" knew where they had eachother. Roles between actors was instiutitionalized. The government did not favor interference in the companies daily production. At the same time companies knew that they had to produce efficiently and effectively so that politicians would not be tempted or provoked to interfere.

The focus of this paper is to look at if and how the relationships between government and state owned companies change once privatization occurs. Do the companies have strong or weak links with government, even if they are supposed to be more market oriented? Have the norms, values and rules - in short institutions changed after privatization? Are privatized companies geared for competition and behave like any other private company, or are they clinging onto their former status as public enterprises? 
One proposition is that some companies are not fit for the "free market" and keep links to government because of shared norms, values and interests. Another proposition is that privatization only makes sense if there is a competitive market and that companies once privatized act in accordance with a market logic of steering. The two propositions are developed further in the theoretical section below which focus on new institutionalist theory and contingency theory in organizational analysis.

The paper is structured as follows: First the theoretical perspectives are discussed in more detail. Second a brief overview of privatization in Denmark since 1990 is presented, including a note on the types of companies that are "privatization candidates". Third government-enterprise relations are examined in the Danish case. Fourth we analyze why some privatized companies cannot let go of the government, and others seem happy and well in the "free market". Fifth I shall point to the future of the relationship between government and privatized enterprises in the wake of further liberalisation and market competition at both the European and the world wide level.

\section{Methodology}

First a theoretical framework for the discussion is constructed using institutional theory and contingency theory. The empirical study of privatized companies in Denmark is based on annual reports from the companies themselves, official reports from the Ministry of Finance, official reports from other government departments and interviews conducted with key actors. Three main propositions are derived from the theoretical literature and then confronted with the empirical findings in Denmark. The empirical data stems from the author's work on state owned enterprises conducted between 1993 and 1996 (Greve 1996).

\section{UNDERSTANDING BUSINESS-GOVERNMENT RELATIONS}

In this section we focus on two main theoretical perspectives. The first is the institutional perspective in organizational sociology which analyzes how ties and bonds between actors can be upheld and how routines are in place. Actors behave according to a logic of appropriateness instead of a logic of consequentiality (March \& Olsen 1989). Organizations, including state owned companies, may have to deal with a public context to seek ressources and legitimacy for their actions ( Meyer \& Rowan 1991 [1977], Brunsson \& Olsen 1993).

The second theoretical perspective focus on how companies, when exposed to competition, should do their best to increase their market share and to show a profit. In contingency terms, we would expect companies to become market-oriented in their behaviour. The transaction cost perspective in organizational theory suggests that the relationship is dominated by change in costs of control (Williamson 1985, 1995). Contingency theories within organizational analysis have stipulated that companies adapt to change in surroundings by organizational design (Gailbraith 1977; Mintzberg 1983). 
The view that organizations have both an institutional environment and a technical environment has been put forward by Scott \& Meyer (1991) and we wil now treat the perspectives in turn.

\section{Emphasis on the institutional environment}

The new institutionalism in sociological organizational analysis focus on norms, rules and values. As often stated many "institutionalisms" exist today (Campbell 1994). Institutions may work at different levels: the regulative level, the normative level and the cognitive level (Scott 1995). We should be aware of formal rules, of informal rules and the interpretative level when analyzing institutions. With regard to state owned enterprises, many formal rules and regulations exist, there is a "public interest" towards the companies and the actors involved with the companies form their own opinion on how a state owned company should act. The whole trust of the new instituitonalism in organizational analysis has been that institutions cannot easily be changed overnight. Institutional theory has long been characterised as pointing to a "stickyness" of institutions which may cause "inefficient" (in the tecnical term) solutions to be put forward (Thelen \& Steinmo 1992: 18).

Although institutions have a conservative element about them, new rules, new norms and new values are not out unlikely to occur. When privatization becomes an issue in politics, it becomes the value of market discipline versus the value of the public interest. New norms of arms length government and competition may be applied to former public enterprises which used to emphasise close relations between government and enterprises. One institutitonalist interpretation is that the norm and value of market discipline is adopted by companies for merely symbolic reasons (Brunsson \& Olsen 1993; Meyer \& Rowan 1991 [1977]. A persuasive argument at first, but exceedingly difficult to work with in practice (Premfors 1996).

The theoretical proposition coming from the institutionalist theory is that value, norms and rules are "left over" from a previous age. If companies take on market mechanisms, it may be done so as to build a "shield" to protect the core business.

\section{Emphasis on the technical environment}

The contingency / market perspective would hold that the environment poses challenges for privatized companies that will affect their relationship with government. Flexibility points to more managerial decision making. As does uncertainty. Contingencies are out of government control. The company must handle them themselves. Consequently, relations with government may be relaxed or diminished.

When public enterprises concentrated on tasks that had to do with infrastructure, contingencies was easily scanned: a monopoly market and no potential competitors in sight. No political attempt was made, in the heyday of European public enterprises after World War II, to change the markets in a foreseeable future. 
The government could not put pressure on the company to perform efficiently. In Denmark this was only partly true as public enterprises were run efficiently according to a major study by Olsen (1993), despite not having formal arms length relationships with government.

The control costs may be lessened when market takes over if certain conditions are fulfilled according to Williamson (1985). The transaction cost perspective points to efficient adaption to the environment like contingency theory, but adds the control costs to the costs of production.

The proposition originiating from this theoretical perspective is that we should examine the state of the technical environment and look at how organizations adapt to changing conditions in an efficient manner. The main environmental feature that privatized companies face is whether they have to sell products on a competitive market or a monopolized one.

TABLE 1

Institutionalized relationships and structure of market

\begin{tabular}{|l|l|l|}
\hline $\begin{array}{l}\text { Relations between government } \\
\text { and enterprise / Structure of } \\
\text { market }\end{array}$ & Institutionalized relations & Few institutionalized relations \\
\hline Competition & $\begin{array}{l}\text { companies cling on to govern- } \\
\text { ment, despite being on a mar- } \\
\text { ket }\end{array}$ & $\begin{array}{l}\text { companies wave good-bye to } \\
\text { relations with government and } \\
\text { compete on the market }\end{array}$ \\
\hline Monopoly & $\begin{array}{l}\text { companies with old stylen } \\
\text { public enterprise relationship: } \\
\text { close links with government }\end{array}$ & $\begin{array}{l}\text { companies enjoy monopoly } \\
\text { status, but have few links with } \\
\text { central government }\end{array}$ \\
\hline
\end{tabular}

Both the theoretical explanations discussed above tend to leave out actors' interests and motives. In the contingency perspective actors should design the organization according to change in the enviroment, otherwise the organizations' fate maybe hopeless. The institutionalist argument, in the form described above, is basiscally a conservative one. In the institutional perspective, the interest-seeking actor has long been a neglected research area, although critisisms of that fact is beginning to crop up from institutionalists themselves. New developments in institutional theory argue that interests do have a role to play in institutional theory (DiMaggio 1988; Scott 1995).

A third explanation is then connected to stakeholder / interest groups. Here, we should look at who benefits from privatization and transformation into state owned companies. Several analysists work in this vein. Dunleavy (1991), for example, states that top bureaucrates bureau-shape and thus reorganize government departments to keep attractive work to themselves. 
According to Wilson (1980) when restistance is not well organised, and pro-change is well organized, change is going to take place. Moe (1995) has argued that organizational structure is an effect of political compromises, i.e. it is illusory to expect organizations to be effective in a technical sense. The proposition coming from this kind from theoretical perspective is that we should look at who benefits from current privatization reforms.

All explanations have something going for them. They could maybe be combined in one theory. However, as that theory has not been developed yet, we will be contend to consider the case for each theoretical explanation in turn. Which one finds most empirical suport in the Danish case? This question will be examined below, but first I present an overview of the Danish approach to privatization.

\section{THE DANISH WAY OF PRIVATIZATION}

Denmark has not been often referred to as a country where privatization has taken place. More attention has been payed to the British experience which had its heyday in the 1980's (Dobek 1993). More recently for its sheer volume, the German privatization effort is demanding attention (Leaman 1994). In Eastern Europe privatization has taken on a more systemic character (Moran \& Prosser eds. 1994).

In Denmark 48 state owned companies exist (1995 figures; Ministry of Finance 1996), many of them have been transformed since 1990. Companies fall in five main groupings (Ministry of Finance 1993: 38-39): infrastructure, suppliers to government (for example computer systems), transfer payment, gambling (state lottery) and cooperation with private companies or with other countries. In companies such as the Danish Oil and Natural Gas company, the government owns $100 \%$ of the shares

Privatization has occured in several of the state owned companies (Ministry of Finance 1996). In 1990 a life insurance company owned by the state was privatized $100 \%$. In 1994 assets were sold in Copenhagen Airport and the company was listed on the stock exchange. The government now owns $51 \%$ of the shares. The big national telecommuication company TeleDenmark have been privatized partly, and the government now owns $51 \%$ of the shares. The Postal Giro was a public enterprise for many years and was then made into a state owned enterprise called GiroBank. First $51 \%$ of the shares were sold. In 1995 the company merged with a commercial bank and formed the BG-Bank. Thus, the Postal Giro was privatized $100 \%$ in the span of four years. A company called The Export Credict Council which finances credits for companies in Denmark exporting goods and service has sold $25 \%$ of its assets to a Dutch company. The computer company Datacentra/ has earlier merged partly with a big Danish company called Maersk. In $199675 \%$ of the assets were sold to the American company Computer Science Corporation. The recently transformed ferrycompany Scandlines is due to sell $25 \%$ of its assets before the end of 1998. 
Although infrastructural tasks like telecommunications, natural gas and railways have usually been the areas in which state owned companies have been set up (Parris, Pestiau and Saynor 1987), no authorative theory is etablished that tells us why, when and how state owned companies emerge, exist or become privatized (Hood 1994: 39). The Danish experience resembles this seeming confusion. Infrastructural companies are operated as state owned companies, yet other types of public service organizations like the fire brigade is run by a privately owned company in many local governments. How organizations became either public or private does not follow a strict pattern, and historical reasons explain why many Danish organizations and services have been come to "belong" to either the public sector or the private sector - or "the grey zone" inbetween (Greve 1996).

According to officialdom privatization is a means of securing a more market based company strategy, and to incorporate expertise on company matters from chief executives or chairmen of the board from the private sector. Privatization must not be a goal in itself according to the present Social Democratic government.

The Danish way has been characterised by pragmatic arguments and not ideology. This is contrary to the British experience cited above. It is also in contrast to, for exampel, the Norwegian experience where more detailed and fundamental debates on state owned companies have taken place (Grøndahl, Øyvind \& Grønlie, Tore 1995). Furthermore, the constitutional hindrance known in Germany, where the government has been prohibited to privatize certain functions has not applied in the Danish case.

There has been a consistent and active reform phase 1990 (Greve 1996). The government has persistently pressed for public enterprises to be transformed into state owned companies. When a strategic partner for state owned companies is on the horizon, shares have been sold to private (and foreign) investors to secure the commercial development of the Danish companies. A motive for privatization that must not be overlooked is the motive to help finance public deficits. Privatization has been an apt policy instrument to save agreements and compromises concerning the state budget between negotiating political parties in parliament.

Summarizing privatization has taken place for mainly pragmatic reason in Denmark. The government has a belief in governability of the privatized companies it wishes to retain control over. Other companies are allowed to drift afloat. Investors generally keep a low profile and have not voiced any discontent with the continuing role for the government as an owner of the remaining part of the shares. 


\section{RECENT DANISH EXPERIENCE WITH PRIVATIZATION}

First I discussed theoretical perspectives on the business-government relationship.

Second I covered the Danish reforms and put them in an international context. In the next section I want to discuss the events in Denmark since privatization. What kind of business-government relationship has Denmark experienced? I will look at the government expectations and companies' strategy, including the use of the current workforce in the companies.

Three sets of questions have risen from the foregoing debate: Are companies behaving according to previous norms, or are they adapting to new norms, and have their been controversies with the government? Are companies exposed to competition in the market? Who had an interest in privatizing public enterprises?

We can divide the findings into three main categories: a) companies which are exposed to market competition, yet retain links with government. b) companies which enjoy monopoly status of some kind and retain links with government and c) companies which are exposed to market competition, while diminishing their relationship with government. There are not any companies in the fourth theoretical category of companies with monopoly status, yet without links to government. Group c) is the largest group and I will devote some time to discuss their situation below, but first, the other two categories are examined briefly.

\section{Companies exposed to competition, but retaining links with government}

We only find one company in this category. TeleDenmark is the largest company. Its controversies with government are few. The government stands behind TeleDenmark, although the company had some nasty decisions to make about redundancies. TeleDenmark sees itself as a private company. Yet the government wants to get the cheapest and best teleservice in the world (Ministry of Research 1995), and the government clearly needs TeleDenmark in that respect. Otherwise, tailor-made regulation seems to be the anwer to government prayers for success in telecommunications. On the whole it is a risky strategy. TeleDenmark may expand abroad, but is equally vuinerable at home. With 17.000 employees TeleDenmark has long sought to diminish the number of workers to secure a competitive position on the market. In early 1997 TeleDenmark announced that around 2000 people were going to be made redundant. While the news were greated with anger by the employees, the cut in the workforce was no news to researchers or stock analysists. TeleDenmark aims at capturing markets abroad as well as securing its position as the leading telecommunications company in Denmark.

\section{Companies enjoying monopoly and retaining links with government}

Copenhagen Airport still has monopoly power, and still is not competing hard like other recently privatized companies. At the same time the company fulfills government objectives, so it is not at odds with government. 
Copenhagen Airport has been labelled a success story by the government. Share prices are up, the company is expanding and new contruction plans for the airport is being implemented. Some employees were not happy to leave their status as government employees and remain "on loan" to the company from the government. While the company does not face any immidiate competition in the capital of Denmark, Copenhagen Airport sees itself in competition with other major airports in the North European region, especially for "hub" passengers. Copenhagen Airport wants to establish itself as the main airport for Scandinavian Airlines System (SAS) and seems to have won over the nearest competitor, Stockholm, in that respect. A whole new terminal will be build for SAS especially.

\section{Companies exposed to competiton with diminishing links to government}

Scandlines is a ferry company which was transformed into a state owned company in 1994, and is going to be privatized before the end of 1998. The values are not shared with the government the way it used to be. Scandlines wants to be able to determine which routes are going to close and which are going to stay open. The company is moving into new business areas as well. The company has recently announced cuts in the workforce. Employees were frustated by the procedure followed by the management announcing the redudancies.

The Export Credit Council (EKR) sold $25 \%$ of its shares to a Dutch insurance company. The Dutch want to expand that share, and make EKR a part of the dutch company strategy. EKR is clearly losing touch with its government lifeline. Plus the company now acts on a competitive market because of new European Union rules that have broken the old national monopolies.

GiroBank was transformed into a state owned company and privatized partly. When the company went into the red one year, a controversy immidiately rose. Also when user charges began to be collected politicians protested on behalf on their constituencies, but nothing came of it. GiroBank behaved like a commercial company that did not take orders from politicians. At first the unions agreed to work in the state owned company instead of a public enterprise. When privatization of $51 \%$ of the shares were announced, the union was furious, yet there was nothing they could do. In 1995 the company was privatized fully merging with one of the big commercial banks and turning into $B G$-bank.

Datacentralen is a company supplying computer systems solutions to government. The company is distancing itself more from government. With the merger with Maersk, the strategy for competing on a purely commercial basis was laid. With the recent sale of $75 \%$ of the assets to the Computer Science Corporation, the route away from government influence seems likely to continue.

Danica was once a public enterprise selling life insurances. In 1990 a decision was made to privatize it, because markets were getting increasingly competitive, and no one in government saw any reason why the government should own its own insurance company. 
The company was sold to one major buyer, another Danish insurance company. Since the privatization, the company has not retained links with government or there have been no political or economic problems with the split.

Summarizing, Companies in charge of major infrastructure, such as TeleDenmark and Copenhagen Airport still uphold their relationship with the government also when market forces challenge their erstwhile monopolies. These companies are still under government influence. The main group of privatized companies, operating on markets are beginning to losen the relationship with government.

TABLE 2

\section{Privatized companies in Denmark: a typology}

\begin{tabular}{|l|l|l|}
\hline & $\begin{array}{l}\text { Institutionalized relations } \\
\text { with government }\end{array}$ & $\begin{array}{l}\text { Few institutionalized } \\
\text { relations with government }\end{array}$ \\
\hline Competition & TeleDenmark & $\begin{array}{l}\text { Scandlines } \\
\text { Export Credit Council } \\
\text { GiroBank } \\
\text { Datacentral } \\
\text { Danica }\end{array}$ \\
\hline Monopoly & & - \\
\hline
\end{tabular}

\section{EXPLAINING BUSINESS-GOVERNMENT RELATIONSHIPS}

How can we explain the current relationships in the light of the theoretical perspectives presented above? The institutionalist argument is appropriate for some of the relationships. Especially for companies with monopoly status intact.

The regulative institutions play a greater role for these companies than normative or coginitive institutions, if we use the distinctions made by Scott (1995) and referred to earlier. But liberalisation of markets has played its part where business-government relations become more distant and arms length, moving towards "American style" arms length regulation.

Shifts in institutionalisation and liberalisation form much of the background for the current relationship between government and recently privatized companies. Instifutionalisation does not seem not very strong though and rests on monopoly status. No company with substantial market competition has yet clung onto government, and liberalisation of markets affects nearly all the privatized companies.

However interest group theory has to be drawn in to explain the actual outcome of the relationships. In Denmark, the Ministry of Finance stand to gain from privatization, both financially and because it leaves them with a flexible policy tool. 
Politicians want to avoid day-to-day trouble and can see an advantage in not being directly associated with cuts in the workforce. Civil servants seeking new carreer opporntunities may also have caused the spur towards privatization. No evidence points to new investors being very active, although banks and consultants have been involved in prior analysis. No company has undergone an analysis with the recommandation that the company should not be transformed or privatized. The option is usually left open, or it is being recommended. Why are companies leaving their links to government behind? At least three tentitative answers can be given.

\section{The "feel good" Factor}

A "feel-good" factor surrounds the whole privatization project. Privatization is a success in a political, economic and administrative sense.

Politically it is a flexible policy tool which will allow future adjustments of the structure of the state in Denmark. Economically, profits are rising steadily and shares prices have risen. Administratively, there are no hard battles in public between government departments and the companies. The government seems to trust in companies' boards and executives in general. Some employees have benefitted from the privatization when they have had an opportunity to buy shares at discounts. However, other employees may remain sceptical.

\section{Changing Norms and Values}

The norms are changing fast within central government as to how much ownership means. Government influence can be retained by regulation if necessary. The government seems to be more favour of the market approach than before. The hesitant periods of the 1980's where privatization and market reform was hush-hush in Denmark (Andersen, Greve \& Torfing 1996) has all but disappeared in official publications.

Applauding privatization because of the supposedly prize of more effectiveness is no longer inappropriate for a Social Democratic government. When TeleDenmark announced a big cut in the workforce as mentioned earlier, the government did not argue with the board of TeleDenmark (at least not in public).

\section{Government Still in Control}

Many reforms in the public sector in Denmark, including prlvatization and corporization, rest on the premise that government is in control still. As of yet there has been no unpleasent surprises from the market. Or scandals in the state owned enterprises themselves. The government feels that it can intervene if privatization goes too far. However, the option to intervene may be severely damaged by privatization, because few private investors will tolerate new and haphazard government interference. 


\section{The Future Relationship}

Whether the "fairytale" story continues in times with liberalization in the European Unions is doubtful at best. However, the avoidance by the Social Democratic goverment of using privatization for ideologal battles for "shrinking the state", leaves the government with a flexible policy tool in the future. The government can continue to sell shares where appropriate, yet it can safely assure the core voters that no neo-rightist agenda is pursued.

The future relationship is dependent on how well the companies perform financially. If a "feel bad" factor should replace the current "feel good" mood, the government and the enterprises can argue over who should be responsible for losses. A "feel bad" factor can occur, if the changes in norms reported above, is nothing but a surface change in rhetorics, as suggested by Brunsson \& Olsen (1993). Finally, if the government is seen to lose control, where it thought it had control, then this can seriously damage privatization in the future. The most likely testcase at the present time of writing in 1997 is the telecommunications company TeleDenmark. Should the national tele company lose out to foreign competitors, then the government can face problems with privatizing other state owned enterprises.

\section{CONCLUSION}

Competition changes the privatized companies' behaviour. Only where government have firm and vital interests still is the relationship with the privatized company upheld. The institutionalists' focus on "sticky" norms and values have not predicted why some companies choose to losen their links to their former owner. An interest group argument provides part of the answer to why the relationship between government and privatized enterprises is diminishing so fast.

The privatization trend seems set to continue. Some companies will continue to adopt market strategies. For them links with government will decrease. Especially if more stocks are sold. Other companies find it hard to get away from the government connection, mainly because of a monpoly status. We have not seen major controversies over company strategies, pay or jurisdiction, but there are emerging problems with major cuts among company employees. However, if problems crop up, the players' strategic positions will be much more visible. Then, the stakeholder / interest group theory will be equally relevant to looking at as institutional ties or market structure.

The Danish privatization scheme's future depends on the following questions. First, the fate of the feel-good factor. Can the companies continue to enjoy financial success? Second, can privatizations be kept pragmatic? Will the temptation to boost about privatizations be too big? Third, will key players like the Ministry of Finance and politicians continue to look at privatization as a useful and managable policy tool, and can the government keep from interfering in company matters? 


\section{References}

Andersen, Kim Viborg; Greve, Carsten \& Torfing, Jacob (1996). "Reorganizing the Danish Welfare State 1982-1993 - A Decade of Conservative Rule" Scandinavian Studies (USA) Spring 1996, Vol. 68, No. 2, pp. 161-187.

Brunsson, Nils \& Olsen, Johan P. (eds) (1993): The Reforming Organization London: Routledge.

Bös, Dieter (1991). Privatization: A Theoretical Treatment Oxford. Clarendon Press.

Campbell, John L. (1994). Recent Trends in Institutional Analysis København: COSResearch Report.

DiMaggio, Paul (1988). "Interest and Agency in Institutional Theory" in Zucker, L. (ed.): Institutional Patterns and Organizations Cambridge, Mass.: Ballinger Publishing Company. pp. 3-21.

DiMaggio, Paul \& Powell, Walter (eds.) (1991). The New Institutionalism in Organiza tional Analysis Chicago. University of Chicago Press.

Dobek, Mariusz Mark (1993). "Privatization as a Political Priority: The British Experi ence" Political Studies XLI, pp. 24-40.

Dunleavy, Patrick (1991). Democracy, Bureacracy \& Public Choice. EconomicExpla nations in Political Science. Hempel Hemstead. Harvester Wheatsheaf Press.

Gailbraith, Jay (1977). Organizational Design Reading, Mass. Addisson-Wesley.

Greve, Carsten (1995). Den grå zone [The Grey Zone]. Copenhagen. Public Sector Condition and Future.

Greve, Carsten (1996). Styring og demokratisk kontrol af statslige aktieselskaber. [Governance and Democratic Control of State Owned Enterprises] Ph.D. dissertation Institute of Political Science, University of Copenhagen (forthcoming 1997).

Grøndahl, Oyvind Nordbrønd \& Grønlie, Tore (red.) (1995). Fristillingens grenser. Statsselskapet - styringsproblemer og reformprocesser gjennom 50 år Bergen: Fakbokforlaget.

Hood, Christopher (1994). Explaining Economic Policy Reversals Buckingham: Open University Press.

Leaman, Jeremy (1994). "Regulatory Reform and Privatization in Germany" in Moran, Michael \& Prosser, Tony (eds.): Privatization and Regulatory Change in Europe Buckingham: Open University Press, pp. 14-34.

March, James G. \& Johan P. Olsen (1989): Rediscovering Institutions New York: The Free Press.

Meyer, John \& Rowan, Brian (1991) [1977]. “Institutionalized Organizations:Formal Structure as Myth and Ceremony" in DiMaggio, Paul \& Powell, Walter (eds): The New Institutionalism in Organizational Analysis Chicago: Unversity Press, pp. 41. 62.

Ministry of Finance, Denmark (1993). Erfainger med statslige aktieselskaber [Experi ences with state owned companies] Copenhagen.

Ministry of Finance, Denmark (1996). Orientering af Finansudvalget om udviklingen i de statslige aktiebesiddelser [Briefing of the Public Accounts Committee on the development in government share holdings]. Copenhagen.

Ministry of Research, Denmark (1995). Bedst og billigst gennem reell konkurrence. [Best and Least Expensive Through Competition] Copenhagen.

Mintzberg, Henry (1983). Structure in Fives. Englewood Cliffs. Prentice Hall. 
Moe, Terry (1995). "The Politics of Structural Choice: Toward a Theory of Public Bureuacracy" in Williamson, Oliver (ed.): Organization Theory: From Chester Banard to the Present and Beyond Oxford. Oxford University Press.

Moran, Michael \& Prosser, Tony (eds) (1994). Privatization and RegulatoryChange in Europe Buckingham. Open University Press.

Olsen, Ole Jess (1993). Regulering af offentlige forsynings-virksomheder i Danmark [Regulation of Public Utilities in Denmark] Copenhagen. Lawyers and Economists' Publishers.

Parris, Pestiau \& Saynor (1987). Public Enterprise in Western Europe London. Croom Helms.

Premfors, Rune (1996). Reshaping the Democratic State: Swedish Experiences in a Comparative Perspective Stockholm: SCORE Report Series no. 4.

Scott, W. Richard (1995). Institutions and Organizations London. Sage.

Scott, W. Richard \& Meyer, John W. (1991): "The Organization of Societal Sectors: Propositions and Early Evidence" in DiMaggio, Paul \& Powell, Walther (eds). The New Institutionalism in Organizational Analysis Chicago. Chicago University Press, pp. 108-140.

Thelen, Kathleen \& Steinmo, Sven (1992). "Historical Institutionalism inComparative Politics" in Steinmo, Sven, Katleen Thelen \& Frank Longstreth (eds.): Structuring Politics. Historical Institutionalism in Comparative Analysis Cambridge. Cambridge University Press.

Vickers, John \& Yarrow, George (1991). "Economic Perspectives on Privatization" Journal of Economic Perspectives Vol. 5. No. 2. pp. 111-132.

Williamson, Oliver E. (1985). The Economic Institutions of Capitalism New York. The Free Press.

Williamson, Oliver E. (ed) (1995). Organization Theory. From Chester Barnard to the Present and Beyond. Expanded Version Oxford. Oxford University Press.

Wilson, James (1980). The Politics of Regulation New York. Basic Books. 


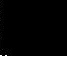




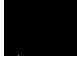


